\title{
Structural Control on Banded Iron Formation (BIF) and Gold Mineralization at Abu Marawat Area, Central Eastern Desert, Egypt
}

\author{
Mohamed K. El-Shafei \\ Department of Structural Geology \& Remote Sensing, Faculty of Earth \\ Sciences, King Abdulaziz University, Jeddah, Saudi Arabia, \\ mshafei@kau.edu.sa
}

Received: 10/3/2010

Accepted: $11 / 4 / 2010$

\begin{abstract}
Abu Marawat area is considered as a promising site for exploration of gold mineralization, where many ancient gold mines, hydrothermal alteration zones, and intervening quartz veins are present. This study is a field-based structural analysis that aims at revealing the relationship between mineral occurrences and local structural setting. The area is a part of a back-arc volcanosedimentary sequence associated with banded iron formation (BIF) that has undergone extensive ductile and brittle deformation history. This multiple deformation is manifested by four phases. $\mathrm{D}_{1}$ and $\mathrm{D}_{2}$ are the product of compressional stresses and are expressed by $F_{1}, F_{2}$ and $F_{3}$ folds in low-grade regionally metamorphosed rocks. $D_{1}$ was a progressive deformational phase started with $\mathrm{F}_{1}$ folds, which in a later stage were overprinted by $\mathrm{F}_{2}$ folds. It resulted from NW-SE-oriented pure shear and is associated with imbricate thrust stacks, which control the locations of listwanite bearing gold. NE-SW-oriented compressive stress during $\mathrm{D}_{2}$ is displayed by $\mathrm{F}_{3}$-slip folds at the early stage followed by N-S- to NW-trending dip-slip normal faults and related shear zones. Mineralized quartz veins (MQV) were developed post- $\mathrm{D}_{2}$ and pre- $\mathrm{D}_{3}$. Folding and refolding in addition to thrust movement play a significant role in shortening and thickening of the iron formation bands located at the summit of Gebel Abu Marawat. $\mathrm{D}_{3}$ and $\mathrm{D}_{4}$ are expressed by brittle deformation. $\mathrm{D}_{3}$ is displayed by conjugate shear planes represented by sinistral-NW-oriented and dextral-NE-oriented strike-slip faults that led to the dislocation and redistribution of gold mineraliztion associated with both MQV and listwanite. Barren quartz veins trending E-W were also developed along gash fractures formed during this phase of deformation. Finally,
\end{abstract}


$\mathrm{D}_{4}$ represents an extensional period that affected the study area and is
manifested by N-S- to NNE-oriented normal dip-slip faults.

The present study has immense significance for gold exploration in providing the essential background to understand the structural elements controlling BIF and gold mineralization. An open pit mine for iron and gold on the eastern slopes of Gebel Abu Marawat is recommended.

Keywords: Abu Marawat, Eastern Desert, BIF, Gold mineralization, Gossans, listwanites, Shear zone, Structural analysis.

\section{Introduction}

Since the last Century the exploration for gold deposits as well as BIF in the eastern desert of Egypt has achieved a great progress. Many studies have been done based on mode of occurrences, classifications, type, and geochemical nature of mineral deposits. In spite of their primitive technology, most of the 96 well-known gold occurrences and deposits (Kochine and Bassuni,1968) were exploited by ancient Egyptians since the pre-dynastic time. The systematic study of the mineral deposits of Egypt began in the past century with the pioneering work of Hume (1937) who made a comprehensive list of mineral occurrences in association with the Precambrian rocks, with notes on stratigraphy, mode of occurrences, and genesis of some deposits.

Mineral deposits of the Eastern Desert were classified by Amin (1955) into seven groups; six of them are of Precambrian age, while the last one includes those of Miocene and younger ages. El Shazly (1957) classified the mineral deposits of Egypt, on the basis of time relations and their mode of formation, into Precambrian, Cretaceous, Miocene and Pleistocene to Recent deposits, with a further classification of the Precambrian group into early and late subgroups. Kochine and Bassuni (1968) classified gold deposits according to the mode of occurrence and the nature of mineralization into three types: dike, vein, and placer types. Sabet and Bordonosov (1984) classified gold deposits in Egypt into three formations: gold-sulfide formation, skarn, gold-ferruginous quartzite formation, and gold quartz formation.

Gold is also found along with some other ore deposits in some Algoma-type banded iron formation (Sims and James, 1984) and in the alteration zones (Botros, 2002). Based on the above observations and the recent crustal evolution models suggested for the evolution of the Nubian 
shield that implies collision of island-arcs and micro-continents through subduction processes (Stern, 1994; and Kusky et al., 2003), Botros (2004) has classified the gold deposits in Egypt into: (1) Stratabound deposits hosted in island-arc volcanics and volcaniclastic rocks which include gold-bearing Algoma-type banded iron formation, gold-bearing tuffaceous sediments and gold-bearing volcanogenic massive sulfide deposits. (2) Non-stratabound deposits hosted in both igneous and metamorphic rocks which include the vein-type mineralization, and disseminated-type mineralization hosted in the hydrothermally altered rocks that have recently become the main target for gold exploration. And (3) placer gold deposits which include the modern and the lithified placers.

BIF are of economic interest as they host the world's largest iron ore deposits and many gold deposits. Fourteen occurrences of BIF have been located, mostly in the central Eastern Desert (Fig. 1). Similar to the iron ores of Archaean and younger volcanic terranes, the Egyptian iron formations are linked in time and space to volcanic activity (Sims and James, 1984; El Habaak and Soliman, 1999; and Basta et al., 2000).

Abu Marawat area $\left(26^{\circ} 26^{\prime}\right.$ to $26^{\circ} 33^{\prime} \mathrm{N}, 33^{\circ} 35^{\prime}$ to $\left.33^{\circ} 42^{\prime} \mathrm{E}\right)$ is known as an Algoma-type BIF in the northernmost part of the central Eastern Desert of Egypt. The presence of ancient mine workings associated with the BIF has attracted several authors to do geochemical exploration for gold in the Abu Marawat area (e.g. Abdel Tawab and Zaki, 1987; Dardir and El Shimi, 1992; Hassanein, 1994; El-Mezayen et al., 1995; and Zoheir and Akawy, 2009). In association with Russian geological teams, the Egyptian Geological Survey and Mining Authority (EGSMA, 1992) carried out a preliminary geochemical exploration program at the Abu Marawat area and reported several zones of geochemical anomalies/hydrothermal alteration potential for gold (Armanious, 1969; Sabet et al., 1976; Sabet and Bondonosov, 1984; Zaki et al., 1987; David, 1988; and Botros, 1993). MINEX Minerals, a subsidiary of U.K. Greenwich Resources Plc, carried out a percussion and diamond drilling program in Abu Marawat area, led to the identification of gold anomalies in two elongate, parallel zones (140 and $230 \mathrm{~m}$ long, and $5-10 \mathrm{~m}$ wide, respectively) of brecciated volcanic/ volcaniclastic rocks and quartz stockwork (David,1988). Eldougdoug (1990) mapped five alteration zones at the Abu Marawat area, in which 
assay data indicated gold concentrations ranging from traces up to $12 \mathrm{~g} / \mathrm{t}$ $\mathrm{Au}$ in the intensively silicified volcaniclastic rocks.

The purpose of the present study is to understand the structural parameters which control the distribution and concentration of gold and BIF at Abu Marawat area. Detailed mapping of quartz veins, BIF, alteration/gossan, and shear zone sites were also carried out during the course of this study.

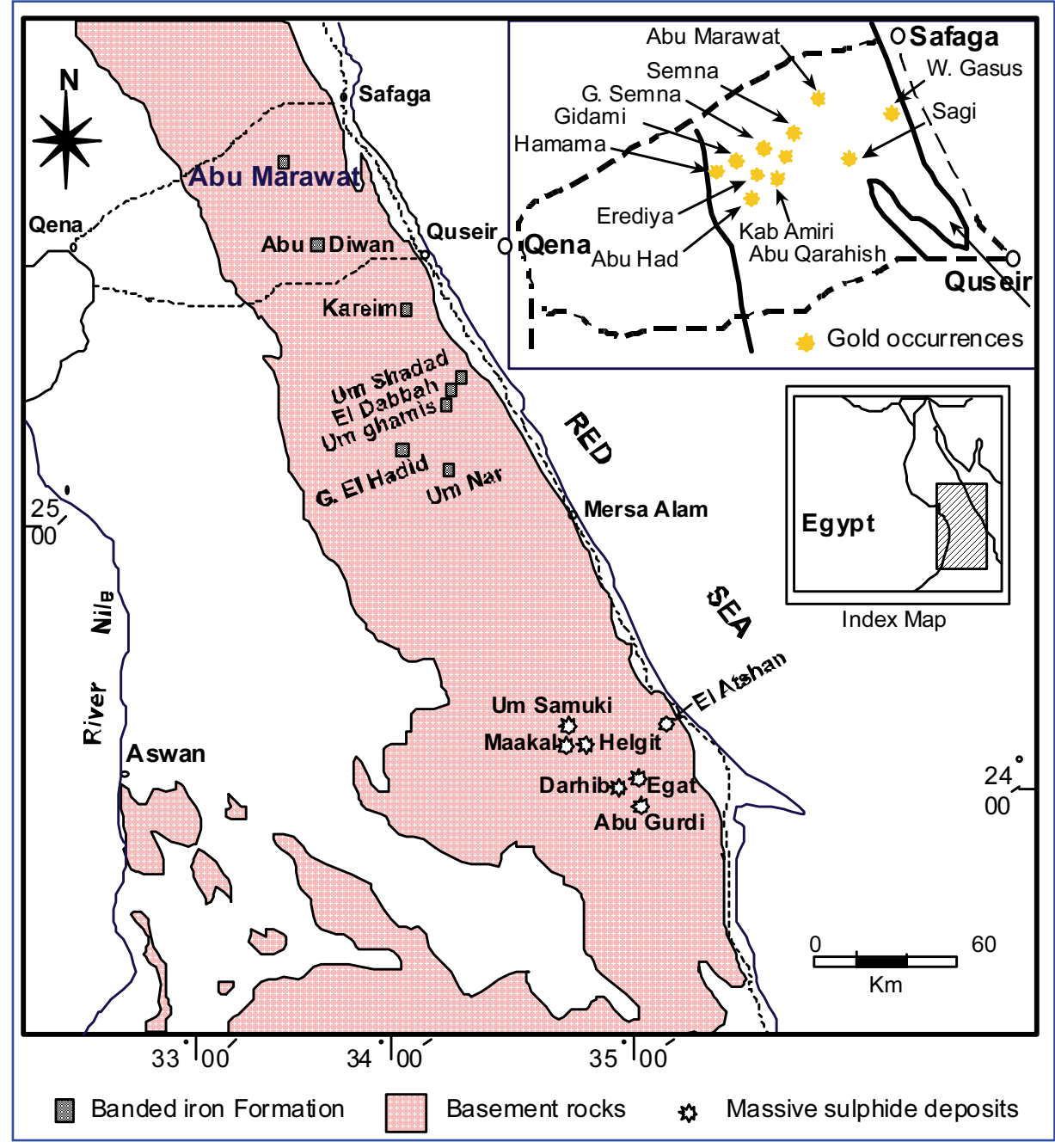

Fig. 1. Location map showing the distribution of BIF and massive sulphide deposits in the Eastern Desert of Egypt. Inset map shows gold occurrences nearby the Abu Marawat area (compiled from Kochne and Bassuni, 1968). 


\section{Regional Geological Setting}

The Arabian-Nubian Shield (ANS), an exposure of Precambrian rocks on the flanks of the Red Sea, that has been controlled by plate collisions associated with the Pan-African event that ended 615- 600Ma ago (Kröner et al., 1992). ANS forms the suture between East and West Gondwana at the northern end of the East African Orogen (EAO). Subduction, starting c. $870 \mathrm{Ma}$, and initial arc-arc convergence and terrane suturing at c. $780 \mathrm{Ma}$, marked the beginning of ocean-basin closure and Gondwana assembly (e.g. Stern and Hedge, 1985). Terrane amalgamation continued until c. $600 \mathrm{Ma}$, resulting in the juxtaposition of East and West Gondwana across the deformed rocks of the shield, and final assembly of Gondwana was achieved by c. 550 Ma following overlapping periods of basin formation, rifting, compression, strike-slip faulting, and the creation of gneiss domes in association with extension and/or thrusting (Johnson and Woldehaimanot, 2003).

The exposed basement rocks of Egypt are represented by the northernmost part of the Nubian Shield that is located to the east of the Nile Valley and the Oweinat area in the western most part of Egypt. It is composed of NW-SE trending allochthonous ophiolitic and volcaniclastic assemblages at greenschist facies, and is extensively intruded by alkaline granitic batholiths and mafic plutons (El-Nisr et al., 2001; and Farahat et al., 2007). These assemblages are overlain by molasse-type sediments that have been deposited during the late stages of the EAO and intruded by calc-alkaline granites with extensional dike swarms indicating transition from subduction through collision and extension after the formation of a juvenile continental crust at about $550 \mathrm{Ma}$ (Vail 1985; and Greiling et al., 1994).

\section{Local Geological Setting}

Abu Marawat area is a part of back-arc basin and is composed of a volcanosedimentary sequence associated with BIF (Fig. 2, 3A). Calcalkaline metavolcanic rocks, showing greenschist facies regional metamorphism, range from mafic to felsic and from massive to sheared. The main rocks are intermediate lava flows and pyroclastics. Metavolcanics are overlaid by immature to semi-mature conglomerate, greywacke, and siltstone of the Hammamat Group (Fig. 2). Slices of altered, strongly foliated $\left(180^{\circ}, 70^{\circ} \mathrm{W}\right)$ ultramafic rocks (dominated by 
talc-carbonate with relic cores of antigorite after olivine) represent occluded ophiolitic oceanic crust (ophiolitic mélange) (Fig. 3A). They are recorded at the northeastern part of the mapped area (Fig. 2) and form $\mathrm{N}$-S-oriented belt of allochthonous, tectonized serpentinite and related listwanite blocks embedded in strongly ductile sheared matrix. They are thrusted over metavolcaniclastic rocks (Fig. 2, 3B). Meta-andesites are predominating in the eastern and northern part of the area, whereas latite and rhyolite occur in the middle. The basic metavolcanics and related tuffaceous units are outcropped mainly at the southwestern part of the mapped area. They are neither altered nor sheared. Whereas the central parts of the mapped area are dominated by altered and sheared metavolcanics of mainly rhyolitic, felsitic, and dacitic rocks and linked to the hydrothermal alteration zones (Fig. 3C) and related mineralized quartz veins (Fig. 3D).

The abundance of sub-aerial silicic lavas in the Abu Marawat metavolcanics suggests that they were erupted from a mature arc (e.g. Habib, 1987; Aly et al., 1991; and Fowler et al., 2006). The massive and foliated mafic metavolcanics and related tuffaceous units are represented by flows and tuffs of meta-andesite and less common metabasaltic flows and agglomerates (Fig. 2). Felsic metavolcanics range in composition from dacite to rhyolite and in texture from banded schistose to tuffaceous. Generally, the metavolcanic rocks exposed at the Abu Marawat area were subjected to multiple deformations and were dislocated along sub-parallel NW-SE-oriented left-lateral strike-slip faults and NE-SW-oriented right lateral strike-slip faults. The displacement is very clear and may reach $1 \mathrm{~km}$ in some places (Fig. 2).

Resistant BIF to the east of Abu Marawat covers an area of about $700 \mathrm{~m} \times 300 \mathrm{~m}$ located mainly on the summit of G. Abu Marawat. Bands of iron up to $3 \mathrm{~m}$ thick are interlayered with slates and phyllites. Few BIF outcrops are intercalated with the metavolcanics as in the mine area to the north of Wadi Abu Marawat. The iron formation-bearing succession of Abu Marawat area attains a thickness of $76 \mathrm{~m}$. The BIF is mainly present in the middle and upper part of the iron formation succession. It is similar to most worlds BIF where the bands are strongly persistent, and show remarkable isoclinal, tight and open fold styles. BIF is present in three main intervals terminating three large depositional cycles (Fig. 4). Each of these large cycles begins with a relatively thick tuffaceous mudstone of dark green color and fine-grained texture at its lower part 
(Fig. 4A), which becomes yellowish green colored and coarse-grained texture toward the middle part of these cycles (Fig. 4B). The mudstones terminated upward by the BIF-bearing intervals (Fig. 4C). The lower parts of these cycles show evidence supporting the deposition during shallow marine environment. This is confirmed by the appearance of yellowish green and red tuffaceous mudstones which indicate the deposition in a slightly oxidizing environment (e.g. Mesaed, 2005). The upper part of the three cycles was deposited in more oxidized environment where it contains red tuffaceous mudstones intercalated with red hematitic iron formation bands as the common setting of Algoma-type (Fig. 4D). Generally, Abu Marawat BIF is located adjacent to Abu Marawat volcanics where iron and silica were derived from hydrothermal sources associated with volcanic centres at the time of formation.

The arc-related plutonic rocks include coarse- and medium-grained gabbro and diorite. Intrusions of syn-tectonic tonalite and quartz-diorite are emplaced in the metavolcanic rocks at the northern and southeastern parts of the mapped area (Fig. 2).

The Hammamat sediments are represented by green to purple pelites, with lesser intervals of arenite ranging from $20 \mathrm{~cm}$ to over $10 \mathrm{~m}$. They strike north and dip toward the east and are located to the west of the mapped area (Fig. 2).

\section{Analysis of Mesoscopic Structures}

The recognized mesoscopic structures were used in this study to reveal the large-scale structures and to reconstruct the local tectonic history of Abu Marawat area. Based on the detailed field mapping and analysis of the structural data, the study area is affected by at least four successive phases of deformation named $\mathrm{D}_{1}, \mathrm{D}_{2}, \mathrm{D}_{3}$ and $\mathrm{D}_{4}$. Compression regime was associated with the first two deformational phases and is characterized by folding, thrusting, early steep dip-slip normal faults, and brittle shear zone. Brittle strains were associated with $\mathrm{D}_{3}$ and $\mathrm{D}_{4}$ and are characterized by strike-slip and dip-slip normal faults, respectively. The following is a detailed description of each structural element and its relation to the deformational history. They include shear zones, smallscale fold hinges, foliations, quartz veins and faults. Geometrical analysis was used to portray and reconstruct the three-dimensional shape of BIF and the gold bearing quartz veins. 


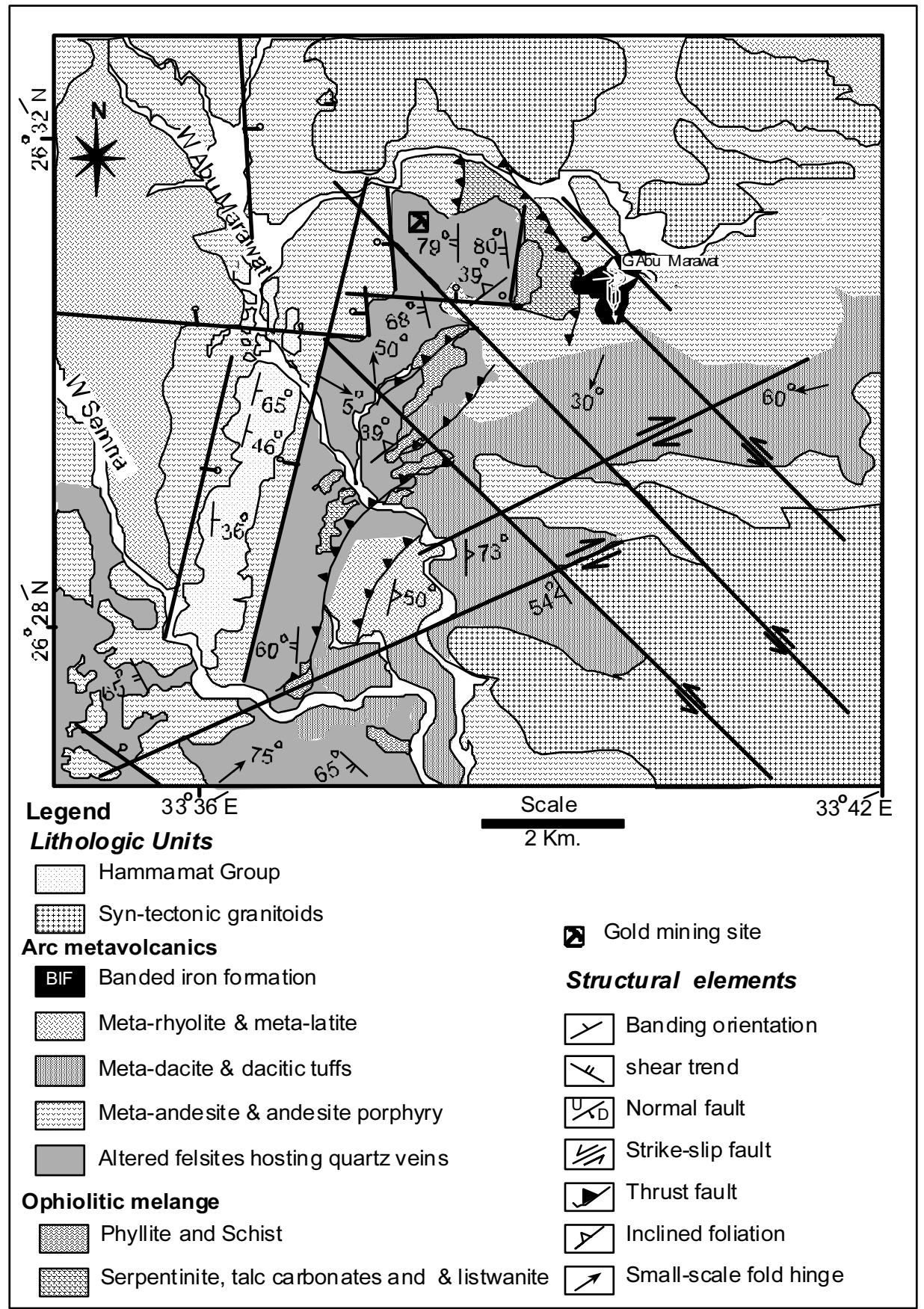

Fig. 2. Geologic map of Abu Marawat area showing alteration zone and the major structural elements. 

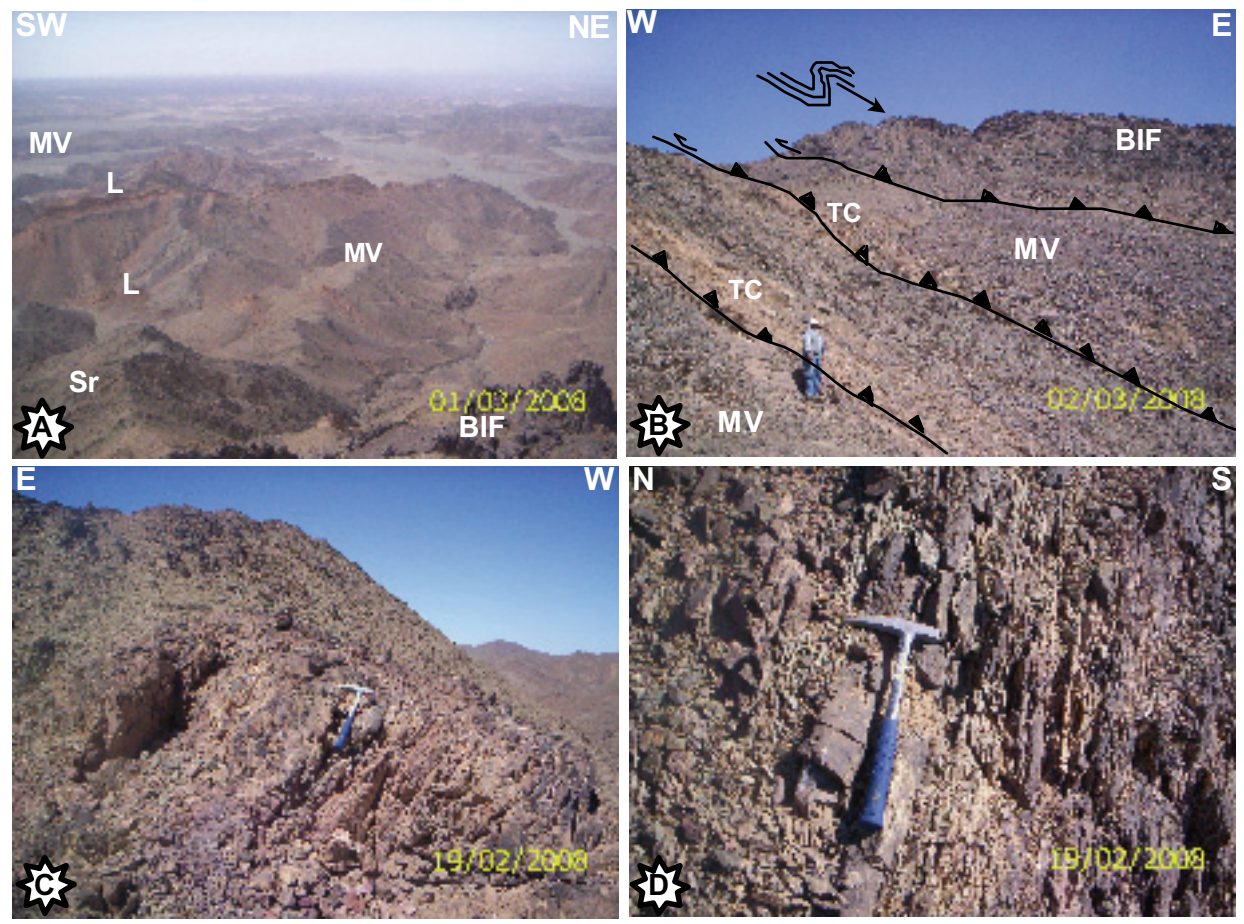

Fig. 3. (A) North eastern side of Abu Marawat area showing BIF, Serpentenite "Sr" and listwanite " $L "$ in contact with metavolcanics "MV", (B) SE-directed imbricate thrust stacks along talc carbonate layers "TC", metavolcanic "MV" (note thrust-propagation folds in BIF), (C) Highly altered and sheared felsic metavolcanics, (D) Swarm of mineralized quartz veins developed along predefined shear fractures in altered rhyolite.

\section{Foliations}

Foliation in the area includes slaty cleavage, phyllitic structures and schistosity in metasedimentary rocks, and fracture cleavage in metavolcanics and BIF. Early foliation " $\mathrm{S}_{1}$ " runs parallel to the bedding $\left(\mathrm{S}_{0}\right)$. Foliations are formed during the early ductile phases of deformation associated with folding. Some axial plane foliations are parallel to the tight fold axes and crossing the hinges. Some foliations are crenulated during the overprinting of $F_{3}$ folding generation. The attitudes of 127 foliation planes are measured throughout the entire area and plotted on stereograms (Fig. $5 \mathrm{~A}$ ). Inspection of the contour diagram of poles to $\mathrm{S}_{1}$ surfaces (Fig. 5A), the rose diagram (Fig. 5B), and the pole diagram (Fig. $5 \mathrm{C}$ ) indicate that the orientation data show some extent of dispersion as an indication of heterogeneous structures occupying the area under 
consideration and the presence of polyphase folding generations. However, two main clusters can be recognized; the first strikes NE and dips to NW at a moderate angle. The second cluster strikes NW and dips to NE at a moderate to steep angle. The sequence of events and the location of major structures are mainly field-based interpretation.
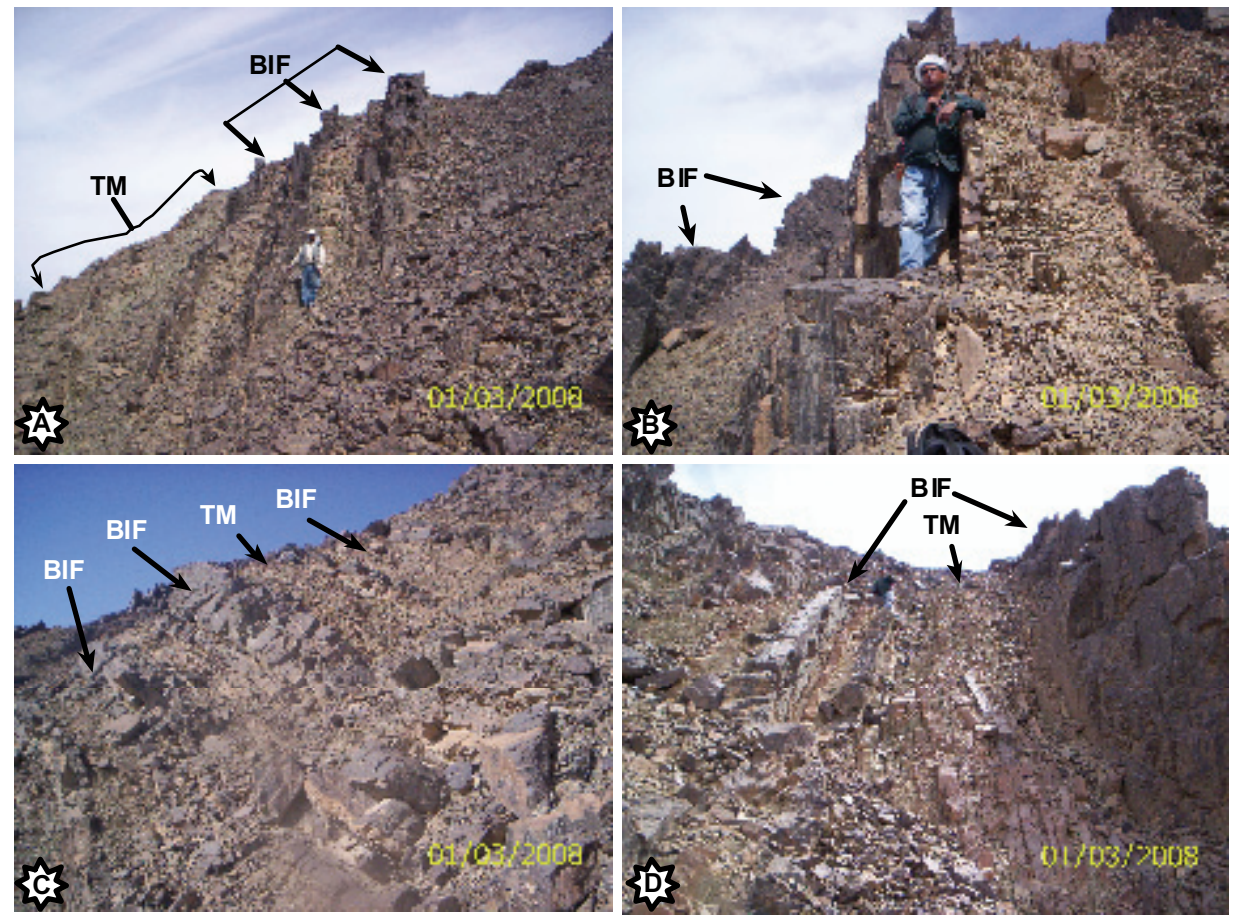

Fig. 4. Field photographs showing large-scale stratigraphic cycles of BIF (A) The lower tuffaceous mudstone "TM" and sheeted IF bands "BIF" of the first cycle, (B) Bedded yellowish green hematitic-magnetitic IF bands "BIF" and red tuffaceous mudstone in the uppermost part of the first cycle, (C) Magnetitic and hematitic- IF bands"BIF" and yellowish green tuffaceous mudstone in the middle and upper part of the second cycle, (D) Red tuffaceous mudstone and red thick hematitic BIF zone of the uppermost part of the depositional cycles.

\section{Mesoscopic Folds}

Mesoscopic folds encountered in the area are recognized everywhere and show variable style and different orientations. They are best recognized in BIF and metasedimentaty rocks. Generally, they are used to locate the large scale folds based on their similarities in both style and orientation (e.g. El-Shafei and Kusky, 2003). 

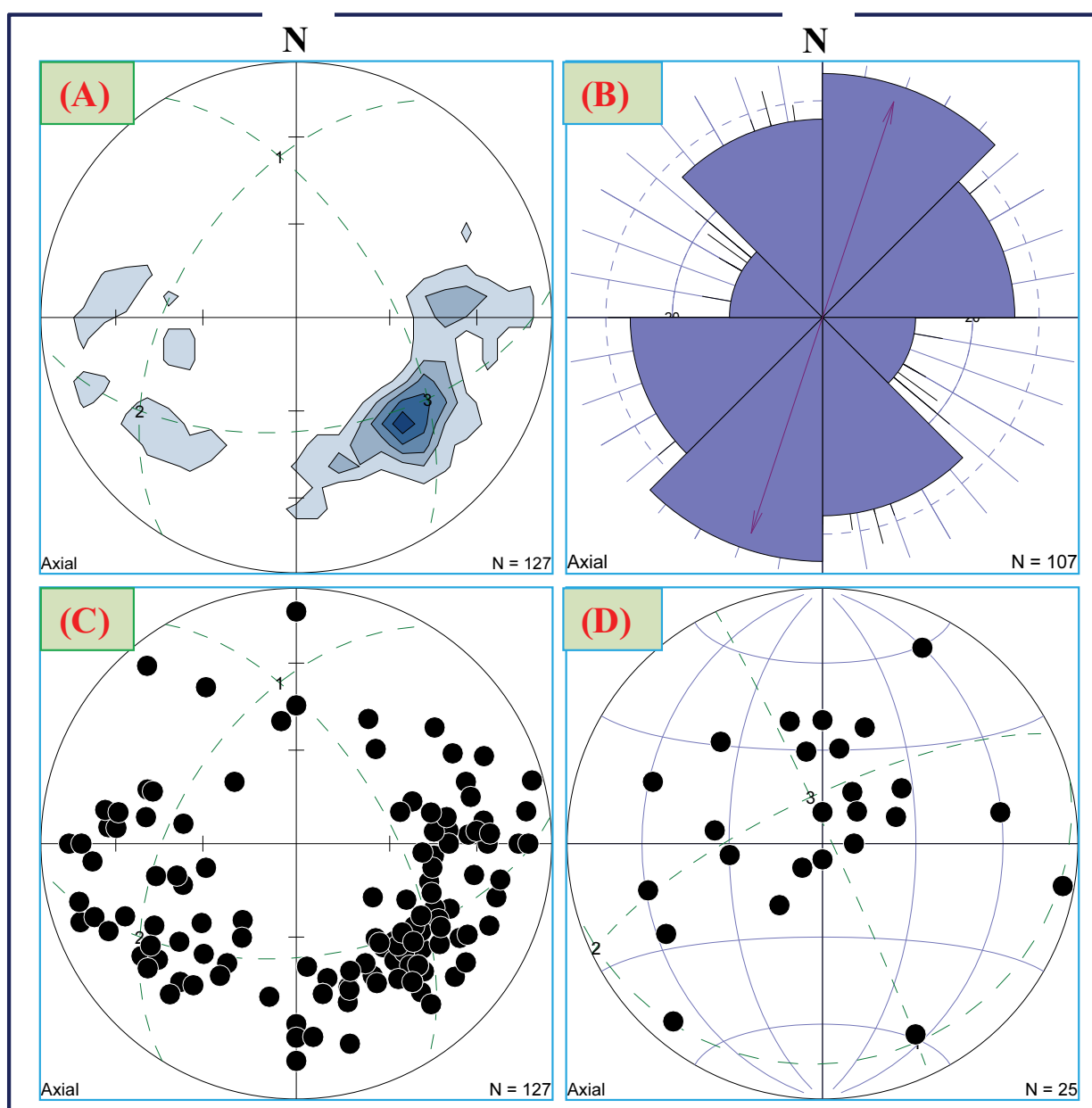

Fig. 5. Lower hemisphere equal-area projections and rose diagram of structural elements (A) Contour diagram of poles to 127 foliation planes (B) Rose diagram shows the strike trends of foliations (C) Pole diagram showing cluster distribution of poles to 127 planes (D) Point diagram of 25 small-fold hinges $\left(\mathrm{F}_{1}\right.$ plunges $31^{\circ}$ due $\mathrm{S62}^{\circ} \mathrm{W}, \mathrm{F}_{2}$ plunges $86^{\circ}$ due $S$ and $F_{3}$ plunges $18^{\circ}$ towards $S 26^{\circ} \mathrm{E}$ ).

Fold types at Abu Marawat area range from isoclinal to open fold styles. They show steeply plunging tight folds (Fig. 6A), E-plunging close folds (Fig. 6B), and SE-moderately plunging open folds (Fig. 6C). Three folding generations $\left(\mathrm{F}_{1}, \mathrm{~F}_{2}\right.$ and $\left.\mathrm{F}_{3}\right)$ are defined based on the recognized interference patterns. BIF shows the effect of superimposed folds and their sequence clearly at the summit of $\mathrm{G}$. Abu Marawat where early isoclinal $\mathrm{NE}$ trend $\mathrm{F}_{1}$ folds are refolded by $\mathrm{F}_{2}$ tight folds (Fig. 6D). 
$F_{1}$ folds are associated with boudin lines (Fig. 7A) parallel to the foliation. Whereas, crenulation foliation is associated with $\mathrm{F}_{3}$ open folds (Fig. 7B). S-plunging $\mathrm{F}_{2}$ folds are refolded by $\mathrm{F}_{3}$ close folds (Fig. $7 \mathrm{C} \&$ D).
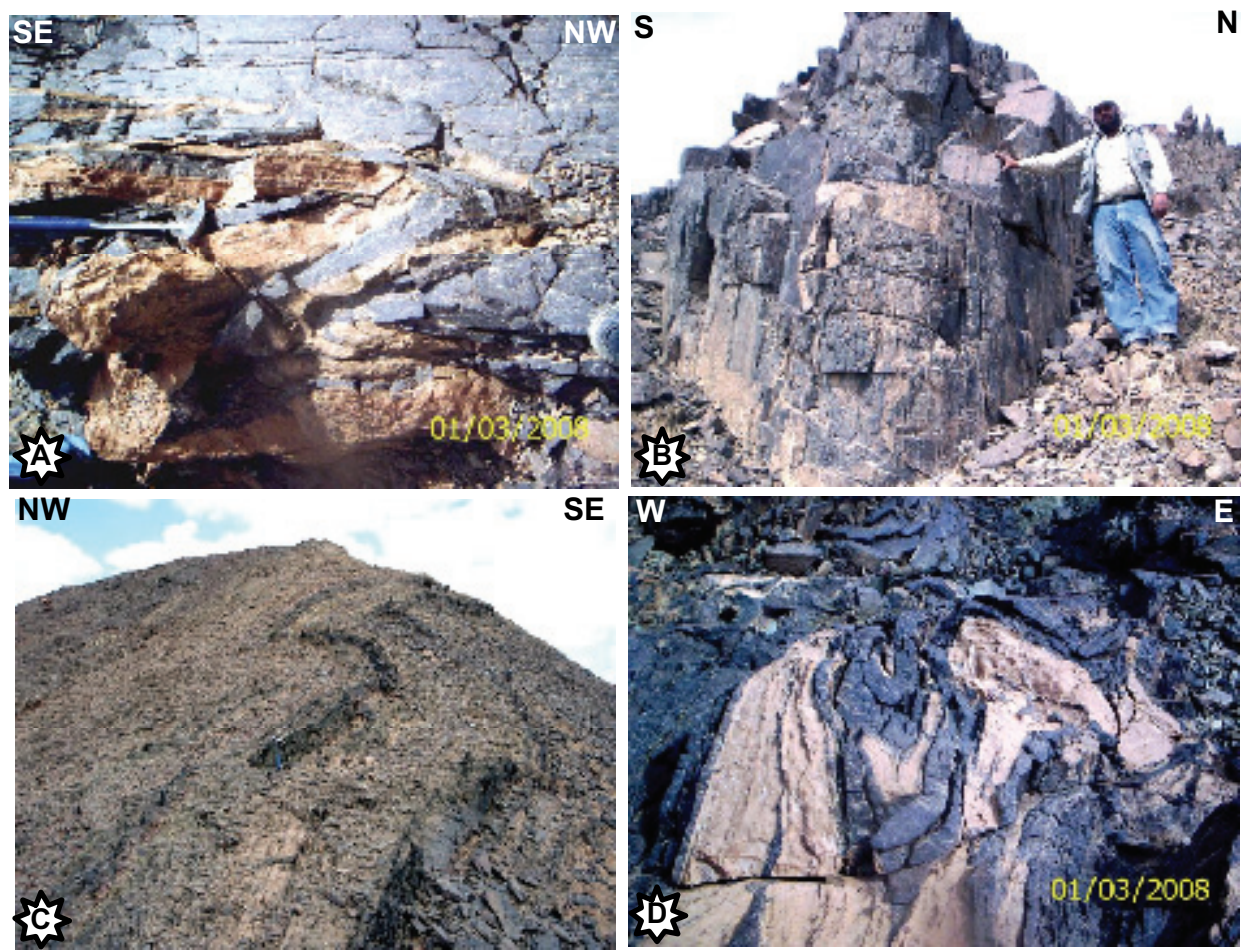

Fig. 6. (A) Tight $F_{1}$ minor fold in BIF (B) Close $F_{2}$ fold of nearly vertical axis (C) SE plunging $F_{3}$ open fold in interlayering of metasediment and metavolcanic units, (D) $F_{1}$ isoclinal fold refolded by $F_{2}$ tight fold with vertical axial plane and steeply plunging due SE.

The attitudes of 30 small fold hinges are measured and projected on an equal-area diagram (Fig. 5D) Inspection of the diagram shows near alignment along a great-circle trending NE-SW and steeply dipping towards NW. The alignment of $F_{1}$ and $F_{2}$ hinges could be interpreted as a consequence of rotation during refolding by $F_{3}$ folds. $F_{1}$ and $F_{2}$ show different orientation throughout the entire area and the pole to the great circle including them defines the orientation of $F_{3}$ open fold axis (Fig. 5D). 
The measured $\mathrm{F}_{3}$ axes are coaxial with the statistically defined axis (Fig. 5D). It plunges $15^{\circ}$ to $\mathrm{S} 29^{\circ} \mathrm{E}$.

\section{Shear Zones}

Shear zones are one of the remarkable tectonic fabrics recognized in both altered and non-altered metavolcanics of Abu Marawat area. They include ductile, brittle-ductile, and brittle shear zones. MQV in metavolcanics and Porphyroclasts recognized in the serpentinite rocks show early ductile shearing. Right-lateral sense of shear shown by S-C fabric relation is an indication of brittle-ductile shearing (Fig. 7E). Brittle shear zones are the most dominant type recognized in the area (Fig. 3D). They are developed either parallel to the early formed metamorphic foliations or are intersecting them. Few conjugate shear planes are also recognized. They were later filled by swarms of mineralized quartz veins (Fig. 3D) of post $\mathrm{D}_{2}$ and pre- $\mathrm{D}_{3}$.

The attitudes of 75 shear planes are measured throughout the entire area. They are projected on a stereogram as poles, great circles and as density distributions (contours) (Fig. 8A). Inspection of the stereoplot (Fig. 8A) and the rose diagram (Fig. 8B) shows that the main shear trends are striking $\mathrm{N} 20^{\circ} \mathrm{W}-\mathrm{S} 20^{\circ} \mathrm{E}$. They are moderately to steeply dipping towards ENE and WSW. They were formed during late $\mathrm{D}_{2}$ as a result of a NNE-SSW-oriented compression regime.

\section{Quartz Veins}

MQV (Fig. 3D) at Abu Marawat area are associated with kaolinized and silicified alteration zones (orange color Fig. 9A). They are most abundant near the northern part (Fig. 9B), less abundant at the middle part and are rare at the southern part of the mapped area where metasediments predominate. The pronounced lithologic control is indicated by the developed of MQV primarily in a rheologically competent mafic and acidic volcanic rock.

MQV typically occur in subparallel swarms crosscut the host rock and run mainly parallel to the metamorphic fabric. Most veins are less than $20 \mathrm{~cm}$ wide and $1 \mathrm{~m}$ long but some larger veins occur, with ca. $2 \mathrm{~m}$ width and 10's of metres in length. At the northern part of the mapped area, they show thicknesses that increase downwards. Few randomly orientated veins and stocks are recorded. Some MQV are developed along conjugate shear fractures. 

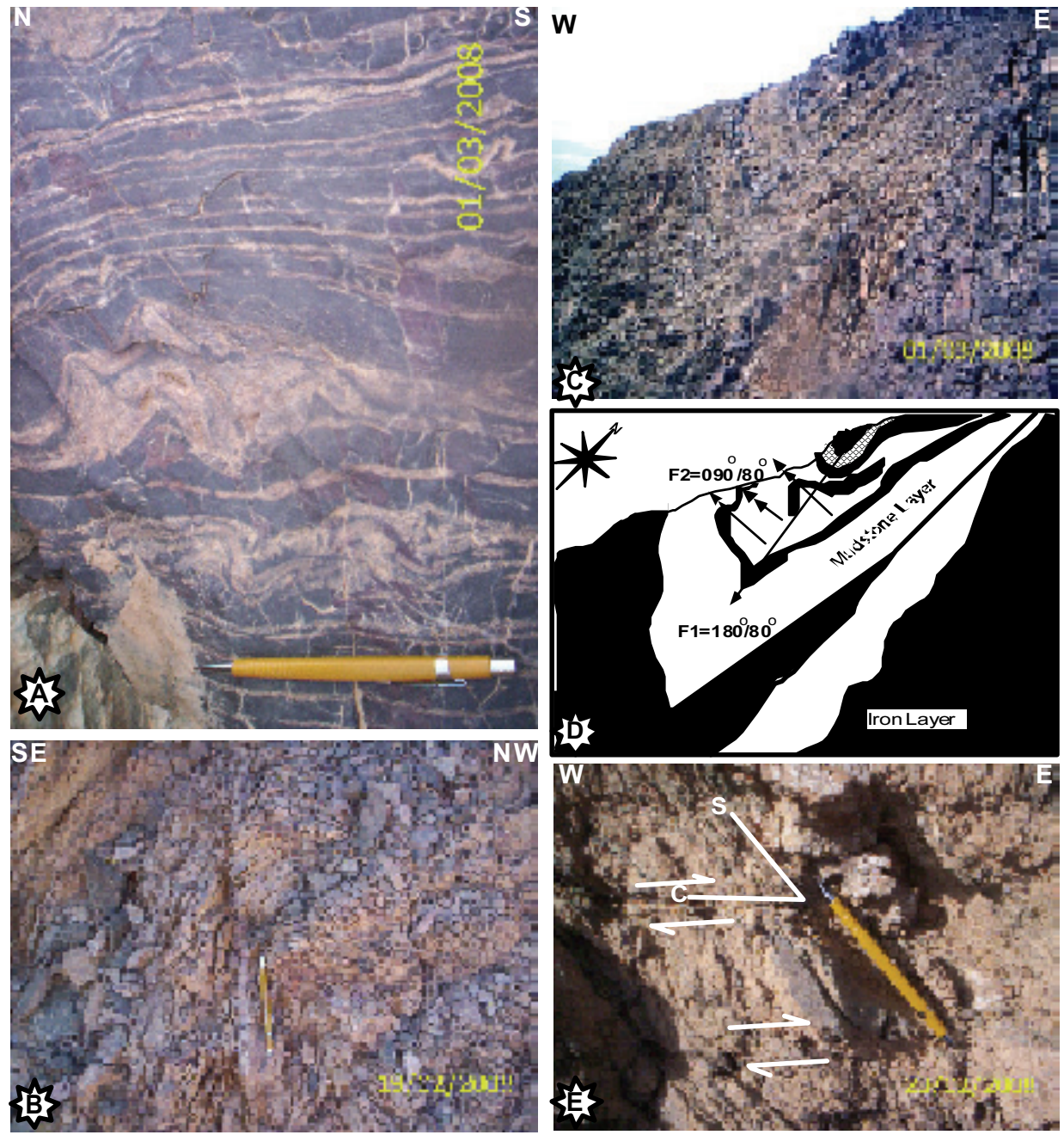

Fig. 7. (A) Silica rich layers in BIF showing boudin lines parallel to $F_{1}$ folds developed in the extension direction, (B) Crenulation foliation $\left(\mathrm{S30}^{\circ} \mathrm{E} / 47^{\circ} \mathrm{NW}\right)$ in metasediment associated with $F_{3}$ open fold, (C) Large-scale tight $F_{2}$ folds refolded by $F_{3}$ closed folds, (D) Traced sketch showing the feature relations in C, (E) S-C fabric indicates right-lateral sense of shear. 


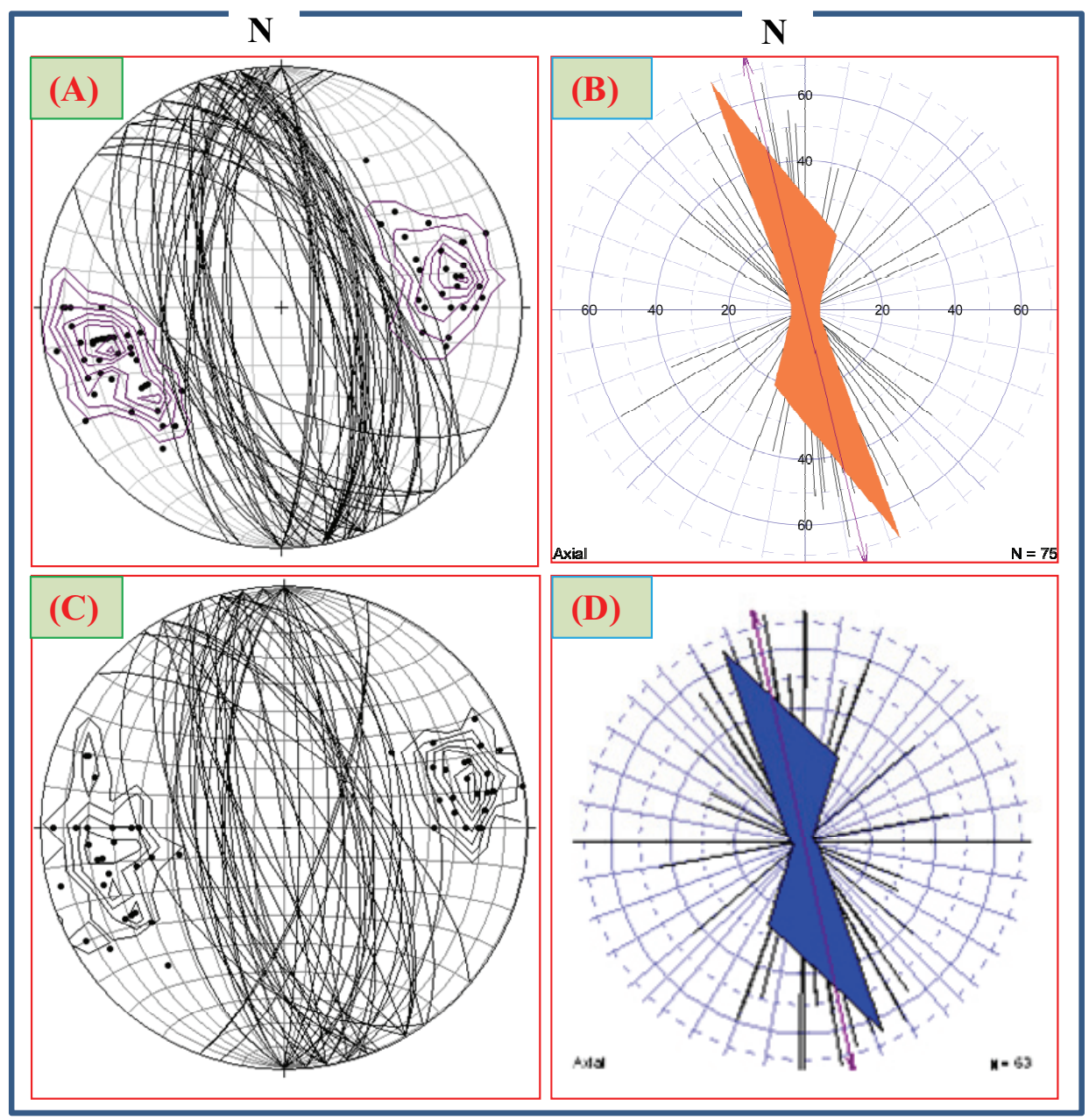

Fig. 8. Lower hemisphere equal-area projection and rose diagram, (A) Pole diagram and its contour equivalent of 75 shear planes, (B) Rose diagram shows the strike trends of the measured shear planes, (C) Pole diagram and its contour equivalent of poles to the mineralized quartz veins, (D) Rose diagram shows the strike trends of 63 mineralized quartz veins. 


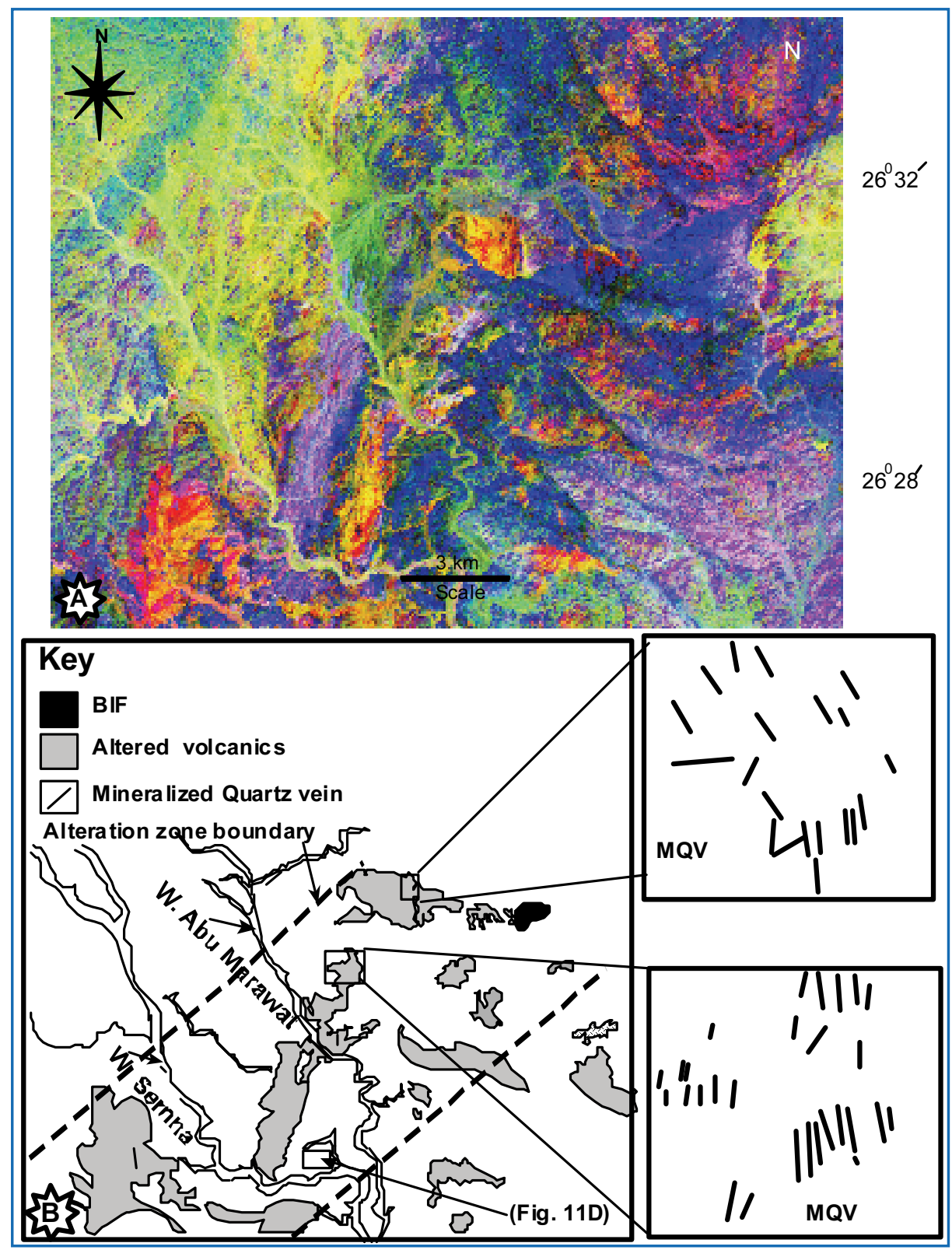

Fig. 9. (A) Landsat ETM ${ }^{+}$band image (bands 5/7, 3/1, 3/5 in RGB) showing the alteration zones in orange color; (B) Traced map of A showing altered volcanic rocks that host the mineralized quartz veins (MQV). 
The attitude of 63 quartz veins are measured and geometrically analyzed. They are plotted as great circles; poles to planes and as contour diagram (Fig. 8C) and are plotted on a rose diagram (Fig. 8D). Investigation of the diagrams shows that they are striking mainly N-S and NNW-SSE with moderately to steeply dipping towards ENE and WSW. It could be concluded that the MQV are running along predefined shear fractures (Fig. 8B\&D). The comparison with the shear zones orientations (Fig. 8B) indicates that $\mathrm{MQV}$ are developed along predefined shear fractures. They are formed post- $\mathrm{D}_{2}$ and pre- $\mathrm{D}_{3}$.

Barren quartz veins (BQV) are developed along tension fractures (Fig. 10A, B). They crosscut the MQV and their metavolcanic host rocks. They are trending mainly $\mathrm{N} 30^{\circ} \mathrm{E}$ and steeply dipping $80^{\circ} \mathrm{SE}$. They represent the final stages of quartz veins in the area and are associated with tension fractures resulted from simple shear stress accompanied with $\mathrm{D}_{3}$ phase. Opening of tensional fractures were parallel to $\sigma_{1}$ and normal to $\sigma_{3}$ (Fig. 10B).

Preliminary field data are collected during this study at the metavolcanic hosting quartz veins at Hamama area located farther west of Abu Marawat (Fig. 1). It indicates similar vein systems, alteration, and structural setting. Mineralization in the area is associated with white quartz veins rich in specular hematite and is developed along shear zone striking $\mathrm{N} 15^{\circ} \mathrm{W}-\mathrm{S} 15^{\circ} \mathrm{E}$ and steeply dipping towards ENE and WSW.

\section{Faulting}

Faults are the most important structural elements that play a significant role in controlling the location and orientations of the mineralized zones. Two types of faults are recorded throughout the mapped area; the dip-slip (normal and reverse) and strike-slip faults (Fig. 2 ). Low angle reverse faults are represented by early overthrust and the development of thrust-propagation folds (Fig. 11A, B) associated with $\mathrm{D}_{1}$ phase. The transport direction was coming from NW directed to SE and resulted in the formation of imbricate thrust stacks (Fig. 11A, B). Mylonitized rocks and listwanite distribution are used to follow and trace the thrust stacks in the area (Fig. 2, 3B). 


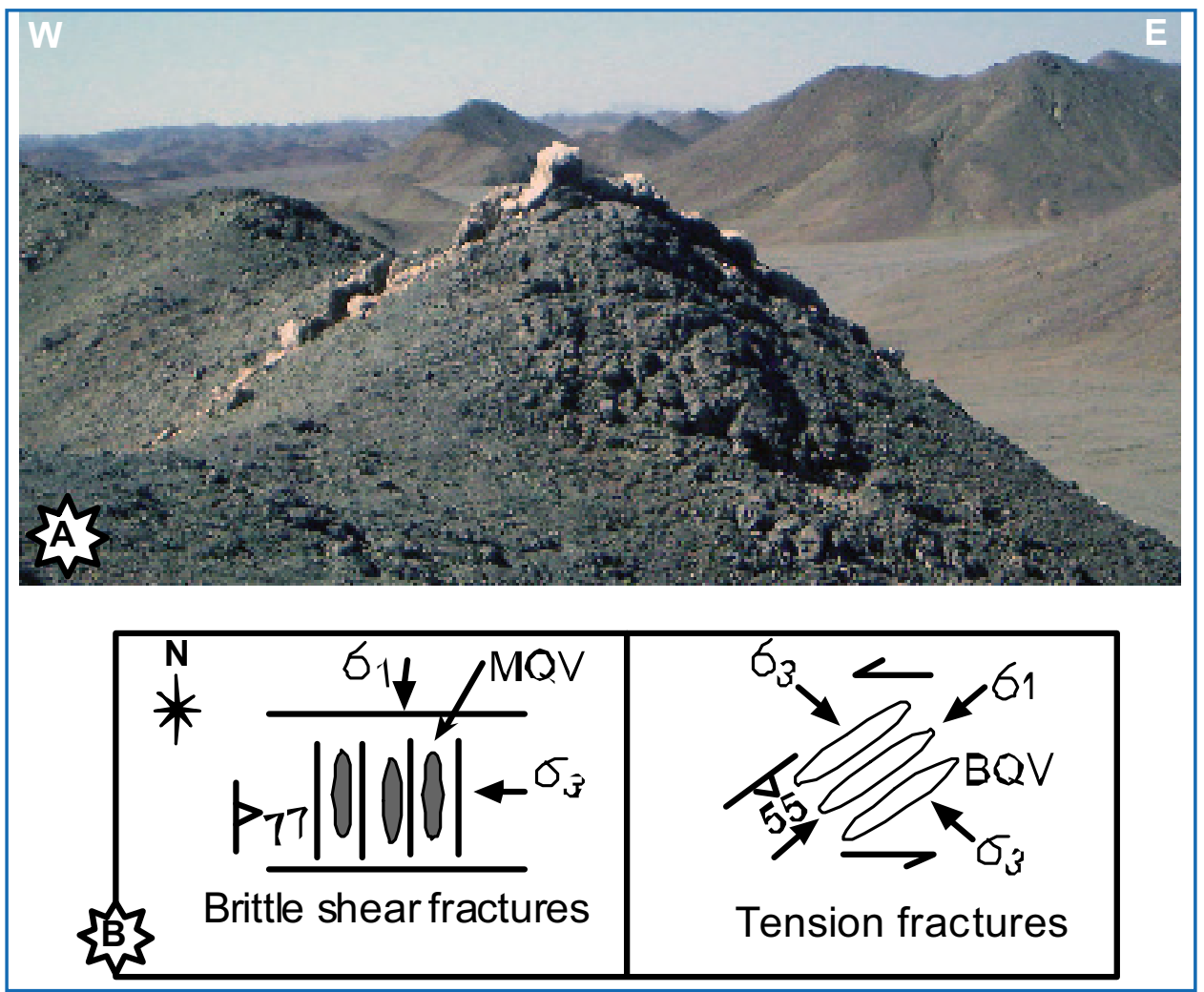

Fig. 10. (A) An E-W-trending barren quartz vein in meta-andsite developed along tension gashes associated with strike-slip faults, (B) Mineralized quartz veins (MQV), barren quartz veins $(\mathrm{BQV})$, and shear fractures relationship with the maximum principal stress axis.

The measured attitudes of the fault planes and their cross-cutting relationship and their relation to mineralized quartz veins indicate the presence of two main fault generations. The early NNE trend with near vertical planes is the only mineralized fault trend and formed contemporaneously with brittle shearing of late- $\mathrm{D}_{2}$. They acted as a channel for movements of hydrothermal solution expressed by alteration and gossan zones. The second group of normal faults strike mainly to NW-SE and NE-SW with moderate dipping toward NE and SE. The local extensional setting of the area facilitated fluid migration from depth. Fluid flow is enhanced adjacent to faults by local extension ascribed to the relative rotation of rigid blocks of host rocks (Fig. 10B). Hence, permeability for mineralization in the northern section is related 
primarily to variable physical disruption of the rocks on a crustal scale at fault intersection zones.

The strike-slip faults trend towards NW-SE and NE-SW (Fig. 2). They are dextral (Fig. 11D) and sinistral faults representing conjugateshear planes that have been formed as a result of simple shear stress oriented nearly E-W during $\mathrm{D}_{3}$ phase. Tensional gashes filled with barren quartz veins accompanied this regime.
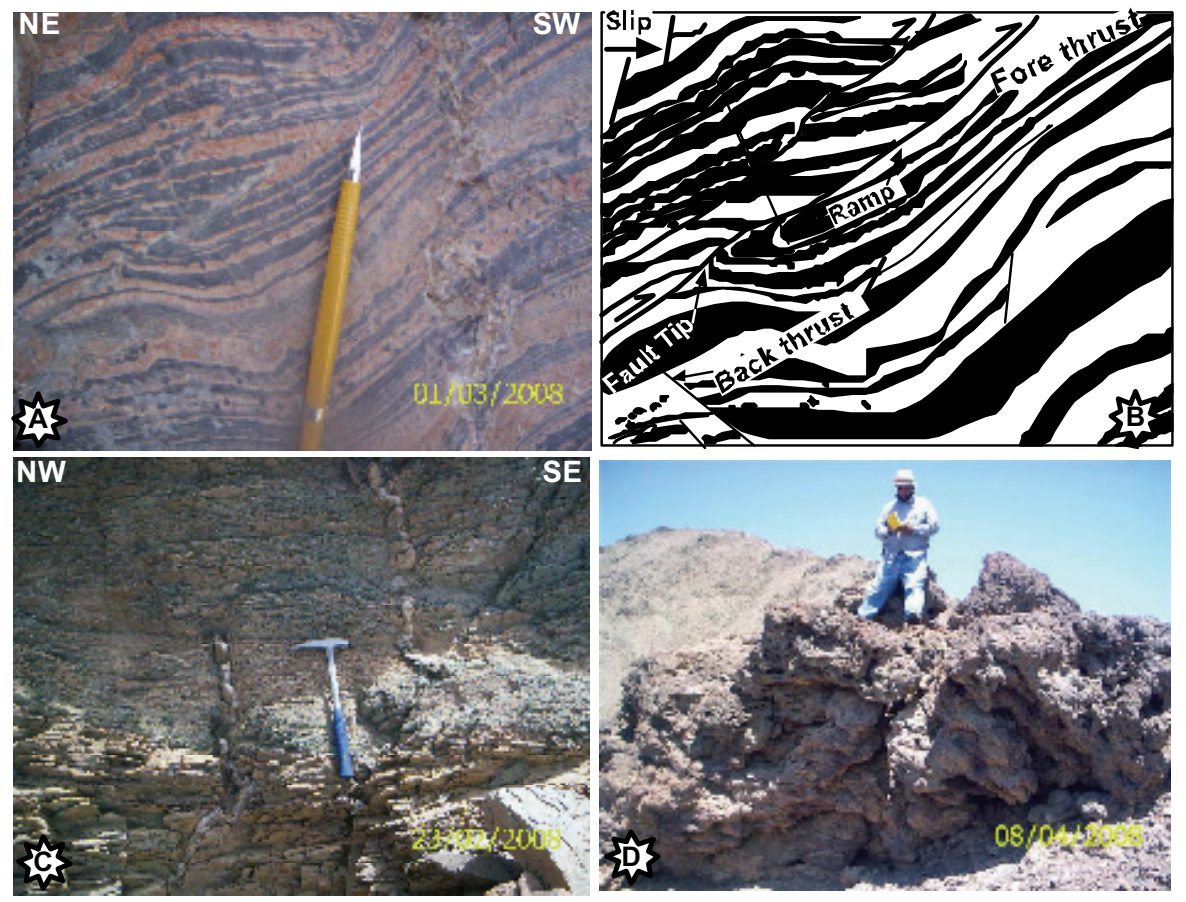

Fig. 11. (A) Minor imbricate thrust stack associated with $\mathbf{F}_{1}$-isoclinal folds, (B) Traced sketch showing the feature relations in A (ramp, thrust plane, direction of slip, kink folds, early $F_{1}$ folds and back and fore thrusts, (C) Sinistral strike-slip fault trending NW-SE and dislocating aplitic dike in metavolcanics, (D) Dextral strike-slip fault in metasediments.

\section{Gossans and Gold Mineralization}

Mesothermal vein type gold deposits are structurally controlled vein systems found in exhumed metamorphic belts, principally in greenschist facies rocks. Economic deposits typically occur close to major crustal structures such as faults or shear zones (Vearncombe et al., 
1989 and Craw and Campbell, 2004). In the study area similar structural elements include shear zones and related alterations are recognized in the metavolcanosedimentary sequence formed under greenschist facies.

Mineralizations at Abu Marawat area are intensely recorded in a wide variety of extensional sites that are dislocated lateraly by regional brittle structures. Rock alteration and gossan zones are enhanced by hydrothermal activity. They are clearly recognized at the intersections of dip-slip normal faults (N-S trend) and shear zones. Altered metavolcanics hosting quartz veins are exposed at the northern and the central parts (Fig. 2\&9A), while iron gossans occur at the southern part of the mapped area (Fig. 11D).

Gossan as defined by Jambor and Blowes (1994) is the name given to a large mass of residual $\mathrm{Fe}$ oxyhydroxide material formed by the oxidation of Fe-bearing sulfide ore deposits. Gossans are oxidized caps that form due to sulfide oxidation, dissolution, and precipitation of secondary minerals. They crop out at the southern part of Wadi Abu Marawat (Fig. 9B) and to the NE of Wadi Semna. Intersections of dipslip normal faults (NW-SE and N-S trends) were the favorable sites for gossans to develop.

Gold occurrences are concentrated mainly along sheared and fracture zones. Vein-type gold mineralization occurs along alteration zones in metavolcanic and metasedimentary rocks. The mineralization is confined to N-S to NNW shear and fracture zones ranging from $5-500 \mathrm{~cm}$ in width and $1-5 \mathrm{~km}$ in length.

The primary ore minerals or phases at Abu Marawat (as reported by MINEX, David, 1988) include a polymetallic sulphide deposit with multi-phase mesothermal vein systems and three phases of mineralization: (1) early high-temperature: pyrite, chalcopyrite, sphalerite, stannite, and galena; (2) low-temperature, low-sulfidation (retrograde metamorphism) pyrrhotite; and (3) low-temperature, highsulfidation pyrite and tellurides. MINEX has drilled from the surface to $60 \mathrm{~m}$ depth in rhyolite and andesite. Grades average $5.3 \mathrm{~g} / \mathrm{t} \mathrm{Au}, 63.3 \mathrm{~g} / \mathrm{t}$ $\mathrm{Ag}, 0.54 \% \mathrm{Cu}$ and $1.8 \% \mathrm{Zn}$. Gold forms fine inclusions dispersed in goethite, limonite, and malachite. Listwanite derived from the alteration of mafic and ultramafic rocks contains an average gold content of 2.7.g/t. Anomalous gold values up to $1.75 \mathrm{~g} / \mathrm{t}$ gold were recorded in BIF. 


\section{Structural Control on Mineralization}

Three main settings are recognized for gold mineralization in $\mathrm{Abu}$ Marawat area: (1) Shear-zone hosting quartz veins. It is characterized by the presence of steeply-dipping NNW-SSE striking quartz veins. The host rocks are mainly altered and sheared meta- rhyolites, felsites, and andesites. (2) Small bodies of hematitic gossans. They are recognized at the southern part of the area and located in weakly to non-altered zones controlled by normal faults intersections and accompanied with few mineralized quartz veins. They may indicate the presence of possible massive sulphide beneath them. (3) 'Listwanite-type' carbonate-altered thrust fault controlled mineralization. Listwanite (carbonatedserpentinite) crops out forming an N-S trending, 800m long serpentinelistwanite belt that has an average thickness of $30 \mathrm{~m}$. The zone is gold bearing and is associated with thrust movement. Similar small-outcrops of listwanite are also distributed throughout the mapped area controlled by a basal thrust fault.

\section{Conclusions}

Gold mineralization at Abu Marawat area in the central Eastern Desert of Egypt is localized mainly in a belt of meta-volcanosedimentary sequence. The near-surface mineralized quartz veins may grade into replacement bodies at depth. The presence of BIF at Abu Marawat is a favorable indicator for gold mineralization related to massive sulphide or iron formation. Gold mineralization occurs throughout the history of the area and developed at many structural levels from the brittle-ductile transition to near surface, and is a normal consequence of collisional tectonics involving mainly greenschist facies rocks.

Structure is arguably one of the principal controls of mineralization. It leads to the formation of high fracture shear zones which provide pathways of enhanced permeability and fluid-flow during syn- and post-metamorphism. This study highlighted the importance of litho-facies, structural evolution, and hydrothermal alteration in the localization of fluid flow at the time of mineralization.

The present structural architecture of Abu Marawat area is the consequence of at least four successive phases of deformation. The exposed metavolcanics and metasediments have been deformed 
extensively by ductile flow. The resulting structures include thrustpropagation folds. These rocks are invariably thrusted and transported towards SE direction. Multiple generations of folding produced a variety of folds interference pattern. Structural sequence that emerged from the geometric analysis includes $\mathrm{F}_{1}$-isoclinal folds associated with thrusting refolded by upright $F_{2}$-isoclinal folds. These $F_{1}$ and $F_{2}$ folds are of flexural-slip nature resulted from pure shear regime that has acted in $\mathrm{NW}$-SE direction. The $\mathrm{F}_{3}$-folds represent the final folding generation overprinting the early-formed folds and plunge $15^{\circ}$ towards $\mathrm{S} 29^{\circ} \mathrm{E}$.

Thrust stacks trending NE-SW are aligned with folds. Both the vergence of folding and the propagation of thrust stacks were towards SE. This deformation was the product of NW-SE compression and is associated with greenschist facies regional metamorphism. These thrust faults control the distribution of serpentinite and listwanite bearing of gold. Folding and refolding in addition to thrust movement play a significant role in shortening and thickening of the iron formation bands located at the summit of Gebel Abu Marawat and provide an easy access for an open pit mining from its eastern side. Few iron fromation outcrops of maximum three meters width are recognized intercalated with metavolcanics and other metasedimentary units.

$\mathrm{D}_{2}$ at outcrops record a switch to NE-SW compression and the development of $\mathrm{SE}$ plunging $\mathrm{F}_{3}$ folds. They overprint the early formed fabrics; $F_{1}$ folds, thrust related listwanite and $F_{2}$ folds. $F_{3}$ are represented by folds oriented NW-SE. Second-order asymmetric folds affecting the limbs of the main structures indicate a slip mechanism of folding in a multilayered and mechanically heterogeneous succession during $\mathrm{D}_{2}$. The axial plane foliations acted as weak planes along which later shear zones and strike-slip faults took place. Brittle shear zones striking mainly NWSE are the channels along which mineralized quartz veins were developed.

During $\mathrm{D}_{3}$ the exhumations of the metamorphic belt led to the formation of conjugate shear planes which may be associated with the Najd Fault corridor. Strike-slip faults are distinguished into NE-SW (dextral) and NW-SE (sinistral). E-W trending tension gashes were developed as a result of simple shear regime which exerted E-W compressive stress. Barren quartz veins were developed later along these tension gashes. 
A switch to crustal extension during $\mathrm{D}_{4}$ and subsequent rotations of the principle stress axes led to granite emplacement and contemporaneous N-S faulting under east-west extension.

\section{Recommendations}

1- Within the volcanic-metasedimentary sequence, the well-known Au-bearing quartz vein(s) are promising prospects. In addition, there is a possibility of Listwanite-type $\mathrm{Au}$ mineralization to occur within the volcanic sequence, particularly in the eastern portion of the mapped area and along the thrust planes.

2- Altered rocks obliterate most of structural parameters used to define the sense of movements and the type of structures controlling mineralization within the alteration zones. It is recommended, based on the detailed survey to explore the area around the alteration zone. Nonaltered rocks will give a clear picture about the situation of these rocks before alteration took place.

3- Thrust related listwanite bodies are considered as suitable sites for gold exploration. Whereas normal and strike-slip faults played a significant role in redistributing quartz veins and their hosting rocks.

4- The occurrence of gold in quartz veins with other sulphides encourages the use of geophysical methods like induced polarization to record differences in conductivity and resistivity at depth and to relate these readings to gold potentials in the mineralized zones.

5- Iron gossans exposed at minor localities in sheared/non-altered metavolcanics at the southern part of Abu Marawat area are recommended for carrying out chemical analyses necessary for mineral exploration.

6- Drilling for new massive sulphide deposits and /or porphyry ores should be targeted where hematitic gossans are well-developed.

\section{Acknowledgements}

The author is grateful to his colleges at the Faculty of Earth Sciences, King Abdulaziz University, Saudi Arabia, especially Profs., Ali Mesaed, Abd Elmonem Eldougdoug, and Ahmed Hegazi for fruitful discussion and continuous encouragement. The author would also like to thank the reviewers Prof. Samir Khawasik and Prof. Mohamed Abdel 
Wahed for their constructive comments. Dr. Nabil El-Masry, Suez Canal University is acknowledged for reading the early version of the manuscript. Mr. Mahmoud Ali and Mr.Yasser Sultan; Teaching Assistants at Suez Canal University are thankful for their assistance during the field work. Alexander Nubia Inc. is acknowledged for providing logistic support at the Abu Marawat Camp.

\section{References}

Abdel Tawab, M. M. and Zaki, M. A. (1987) Geochemical exploration, Abu Marawat gold mine', Internal Report, Egyptian Geological Survey, Cairo, Egpyt, 114.

Aly, N. A.; Hegazy, H. A. and El Tigrawy, A. A. (1991) Geology and petrochemistry of the arc volcanics in the Semna area, southwest of Safaga, Egypt', Bull. Fac. Sci., Assiut Univ., 20: $61-78$.

Amin, M. S. (1955) Geology and mineral deposits of Umm Rus Sheet. Geol. Survey Egypt. Cairo, 1955, 51p.

Armanious, L. K. (1969) Gabel Abu Marawat iron ore deposit, Eastern Desert of Egypt, Internal report, Geol. Surv. Egypt.

Basta, F. F; Takla, M. A. and Maurice, A. E. (2000) The Abu Marawat banded iron formation: geology, mineralogy, geochemistry and origin, Proc. $5^{\text {th }}$ Conf. on 'The geology of the Arab World', Egypt, Cairo University, 319-334.

Botros, N.S. (1993) New prospects for gold mineralization in Egypt. Ann. Geol. Surv. Egypt,. 19: $47-56$.

Botros, N.S. (2002) Alteration zones: are they good target for gold deposits in Egypt. Egypt. Arab Gulf J. Sci. 20 (4): 209-218.

Botros, N.S. (2004) A new classification of the gold deposits of Egypt. Ore Geology Rev. 25: 137.

Craw, D. and Campbell, J. R. (2004) Tectonic and structural setting for active mesothermal gold vein systems, Southern Alps, New Zealand. Journal of Structural Geology, 26: 995-1005.

Dardir, A.A. and El Shimi, K.A. (1992) Geology and geochemical exploration for gold in the banded iron formation of Um Nar Area, central Eastern Desert, Egypt. Ann. Geol. Surv. Egypt, 18: 381-409.

David, J. H. (1988) Abu Marawat prospect, Central Eastern Desert of Egypt: a review and assessment of work carried out by MINEX-Minerals, Egypt', Internal report, Geol. Surv. Egypt.

EGSMA (1992) Geologic map of Al Qusayr Quadrangle, Egypt, Geol. Surv. Egypt, Cairo.

Eldougdoug, A. (1990) Gold anomalies in the Late Proterozoic felsicmafic volcano-sedimentary sequence and associated rocks, Gebel Abu Marawat area, Eastern Desert, Egypt', Bull. Fac. Sci., Cairo Univ., 1990, 58: 533-548.

El Habaak, G. H. and Soliman, M. F. (1999) Rare earth element geochemistry of the Egyptian banded iron formations and the evolution of the Precambrian atmosphere and ocean', Proc. $4^{\text {th }}$ Conf. on 'Geochemistry', Alexandria, Alexandria University, 2: 149-160.

El-Mezayen, A. M.; Hassaan, M. M.; El-Hadad, M. and M. M. Hassanein (1995) Petrography, geochemistry and ore microscopy of Abu Marawat metavolcanics and associated gold mineralisation, North Eastern Desert, Egypt', Bull. Fac. Sci., Al-Azhar Univ., 6: (2), 1999-2021. 
El-Nisr, S. A.; El-Sayed, M. M. and Saleh, G. M. (2001) Geochemistry and petrogenesis of PanAfrican late- to post-orogenic younger granitoids at Shalatin-Halaib, south Eastern Desert, Egypt. Journal of African Earth Sciences, 33 (2): 261-282.

El-Shafei, M. K., Kusky, T.M. (2003) Structural and tectonic evolution of the Neoproterozoic Feiran-Solaf metamorphic belt Sinai Peninsula: implications for the closure of the Mozambique Ocean. Precam. Res. 123: 269-293.

El Shazly, E. M. (1957) Classification of Egyptian mineral deposits. Egypt. J. Geol., 1: 1-22.

Farahat, E. S.; Mohamed, H. A.; Ahmed, A. F. and El-Mahallawi, M. M. (2007) Origin of Iand A-type granitoids from the Eastern Desert of Egypt: Implications for crustal growth in the northern Arabian-Nubian Shield. Journal of African Earth Sciences, 49 (1-2): 43-58.

Fowler, A.; Ali, K. G.; Omar, S. M. and H. A. Eliwa (2006) The significance of gneissic rocks and synmagmatic extensional ductile shear zones of the Barud area for the tectonics of the North Eastern Desert, Egypt', J. Afr. Earth Sci., 46: 201-220.

Greiling, R.O.; Abdeen, M.M. and Dardir, A.A. (1994) Structural synthesis of the Proterozoic Arabian-Nubian Shield in Egypt. Geologische Rundshau, 83: 484-501.

Habib, M. E. (1987) Arc ophiolites in the Pan-African basement between Meatiq and Abu Furad, Eastern Desert, Egypt, Bull. Fac. Sci., Assiut Univ., 241-283.

Hassanein, M. (1994) Geology and Gold Mineralization of Abu Marawat Area, Central Eastern Desert, Egypt. A PhD Thesis submitted to Geology Department Al-Azhar University, Cairo, Egypt.

Hume, W. F. (1937) Geology of Egypt, V.II, Part III, The minerals of economic values, associated with the intrusive Pre - Cambrian igneous rocks and ancient sediment and method. Geological Survey of Egypt. 689 - 990.

Jambor, J. L. and Blowes, D.W. (Eds.) (1994) Short course Handbook on Environmental Geochemistry of Sulfide Mine-wastes. Mineralogical Association of Canada, Nepean, 22: $438 \mathrm{pp}$.

Johnson, P. R. and Woldehaimanot, B. (2003) Development of the Arabian-Nubian Shield: Perspectives on accretion and deformation in the northern East African orogen and the assembly of Gondwana. In: YOSHIDA, M., WINDLEY, B. F. \& DASGUPTA, S. (eds) Proterozoic East Gondwana: Supercontinent Assembly and Breakup. Geological Society, London, Special Publications, 206: 289-325.

Kochin, G. G. and Bassiuni, F. A. (1968) The mineral resources of the URA, Report on Generalization of Geological data on mineral resources of the URA carried out under contract 1247 in 1966-1968, Part I, Metallic minerals: Internal Report, Geol. Surv. of Egypt, 18: 418 P.

Kröner, A., Todt, W., Hussein, I.M., Mansour, M. and Rashwan, A.A.A. (1992) Dating of late Proterozoic ophiolites in Egypt and the Sudan using the single zircon evaporation technique. Precambrian Research, 59: 15-32.

Kusky, T.M., Abdelsalam, M.G., Tucker, R.D. and Stern, R.J. (2003) Evolution of the East African and related Orogens, and the assembly of Gondwana. Precambrian Research, 123: (2-4), 81-337.

Mesaed, A. A. (2005) Stratigraphic setting, facies types and origin of Wadi Kareim Banded Iron Formation, Eastern Desert, Egypt. Proceedings the $I^{\text {st }}$ International Conference on the Geology of the Tethys. Cairo University 11-14 November, 1: 69-90.

Sabet, A.H. and Bordonosov, V.P. (1984) The gold ore formations in the eastern desert of Egypt. Ann. Geol. Surv. Egypt, 16: 35-42.

Sabet, A.H.; Tscgoev, V.B.; Bordonosov, V.P.; Babourin, L.M.; Zalata, A.A. and Francis, M.H. (1976) On gold mineralization in the eastern desert of Egypt. Ann. Geol. Surv. Egypt, 6: 201-212.

Sims, P.K. and James, H.L. (1984) Banded iron formation of later proterozoic age in the Central Eastern Desert, Egypt: geology and tectonic setting. Econ. Geol. 79: 1777-1784. 
Stern, R. J. (1994) Arc assembly and continental collision in the Neoproterozoic East African Orogen: implications for the consolidation of Gondwanaland. Ann. Rev. Earth Planet. Sci., 22: 319-351.

Stern, R.J. and Hedge, C.E., (1985) Geochronologic and isotopic constraints on Late Precambrian crustal evolution in the Eastern Desert of Egypt. American Journal of Science, 285: 97-127.

Vail J. R. (1985) Pan-African (Late Precambrian) tectonic terrains and the reconstruction of the Arabian-Nubian Shield. Geology, 13: 839-842.

Vearncombe, J.R.; Barley, M.E.; Eisenlohr, B.N.; Groves, D.I.; Houstoun, S.M.; Kwarnecki, M.S.; Grigson, M.W., and Partington, G.A., (1989) Structural controls on mesothermal gold mineralization: examples from the Archean terranes of southern Africa and Western Australia. In: Keays, R., Ramsay, R., Groves, D. (Eds.), the Geology of Gold Deposits. Economic Geology Monograph, 6: 124-134.

Zaki, M. E., Botros, N. S.; Zakhari, N. and Abdel Tawab, M. M. (1987) Geochemical exploration of Abu Marawat and Fatiri gold ore deposit, Internal report, Geol. Surv. Egypt.

Zoheir, B. and Akawy, A. (2009) Epigenetic BIF-hosted gold lodes at the Abu Marawat area, Eastern Desert, Egypt: integrated mineralogical, structural control and fluid inclusion studies. Applied Earth Science (trans. inst. min. metall. b) 118 (2). 


\section{التحكم التركيبى في منكون الحديد الثرائطي وتمعدنات الذهب بمنطقة أبومروات بوسط الصحراء الثرقية، مصر}

\section{محمد كامل الثافعي أبوالعينين}

قسم الجيولوجيا البنائية والاستشعار عن بعد، كلية علوم الأرض جامعة الملك عبدالعزيز - جدة - المدلكة العربية السعودية

الدستخلص. منطقة أبومروات تضم تتابعًا من الصخور المتحولة

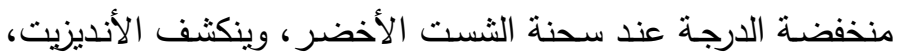

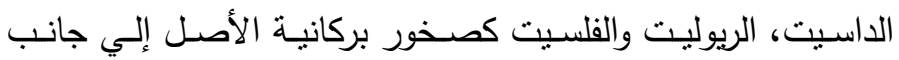

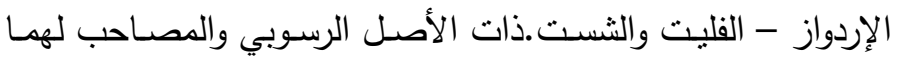

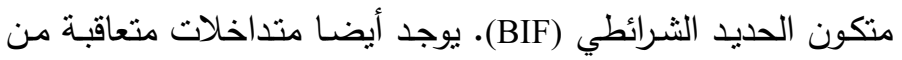
الصخور النارية الجوفية مثل الجرانيت والديوريت. شواهد حفر قديمة

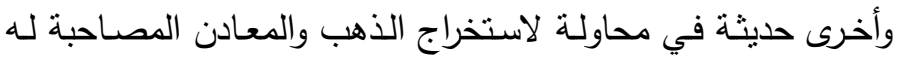
بعدد من عروق الكوارتز المنكثفة على السطح أدى إلى لفت الانتباه

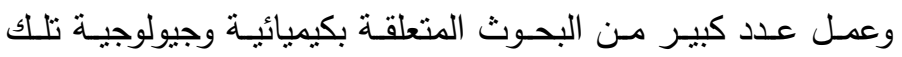

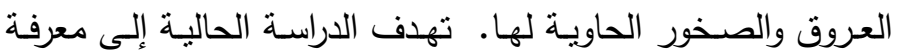

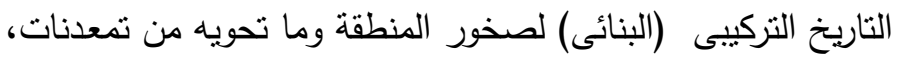

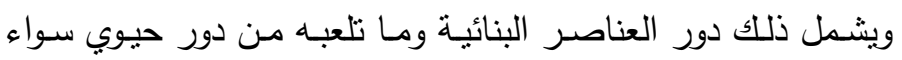

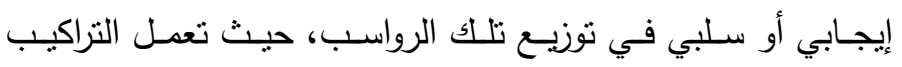
الجيولوجية المتعاقبة على توجيه - تركيز - إخفاء أو إزاحة للصنخور

$$
\text { ورواسبها المعدنية. }
$$

أسفرت نتائج المسح التقصيلي لمنطقة الدراسة من مشاهدات

حقلية وقياسات للعناصر البنائية علي الننائج والتوصيات النالية:- 
1- صــخور المنطقــة الحاويــة لعـروق الكــوارتز الحاملـــة للتمعدنات تمثل نطاقات قص هشة ونطاقات تغير حرمائية. r- توجد عروق الكوارتز بكثرة في الصخور البركانية كششود شبه منوازية على شقوق القص. كما توجد بقلّة في الصخور الرسوبية

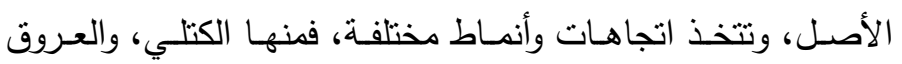
السميكة، والعروق الدقيقة، كدلالة على كونها نمت على شقوق سابقة التكوين وفي مراحل متعاقبة.

r- عـروق الكـوارتز موجـودة فـي الصــور البركانيــة سـواء القاعدية أو الحامضية المتغيرة منها أو غير المتغيرة. ع- تنتشر عروق الكوارتز شمال وادي أبومروات، وتقل كلما اتجهنا جنوبا متخذة من اتجاه شمال شمال غرب مضربا لها، وبدرجة ميل متوسط إلى شديد جهة الثمال الثرقي. 0- تظهر صـور الجوسـان بـالقرب مـن وادي سـنة جنوب وادي أبومروات.

7- نطاق الجوسـان محصور بين منجم أبومروات ومنجم

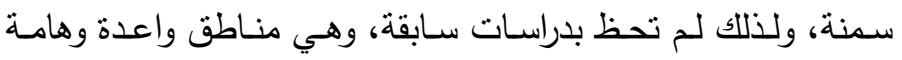

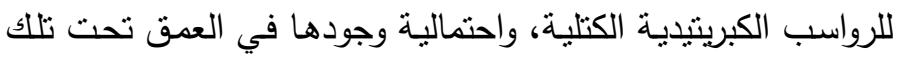

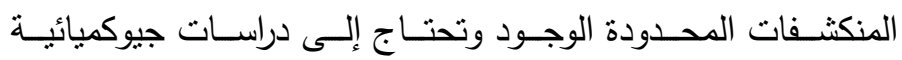
وجيوفيزيائية. listwanite موجـودة لبس فقط في

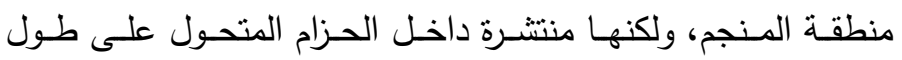

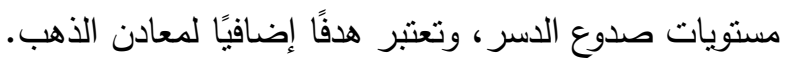
1- لعب الطي دورا حيويا في تقصير وتركيز طبقات الحديد،

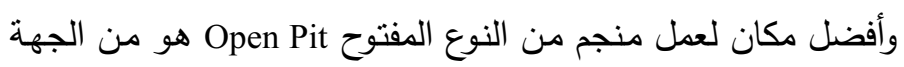


الشرقية، حيث بستغل الحديد ومعادن الذهب المصاحبة له. تم أيضـا خلال تلك الدراسة معرفة الوضع الهندسي لطبقات الحديد فى الأبعاد الثلاثية. 9- تم استتناج أربعة أطوار من التشوة المتعاقب من خـلال

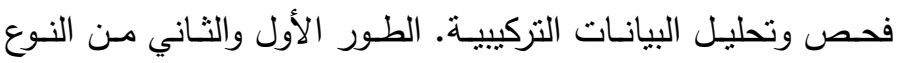
التضاغطي compressional، والذي أدى إلى تحول إقليمي لصخور

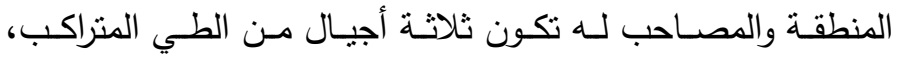

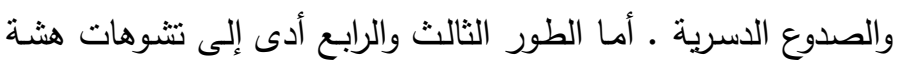

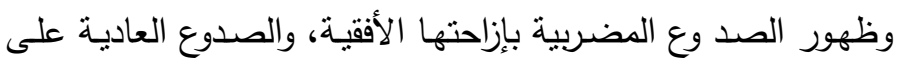
التوالي.

• 1 - تــم ربـــ أطــوار التشــوه المتعاقبـة بنوعيـة التمعـدنات

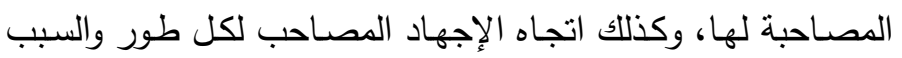
وراء تعدد نمط واتجاه التشوه. 